\title{
Transcription factor control of growth rate dependent genes in Saccharomyces cerevisiae: A three factor design
}

\author{
Alessandro Fazio ${ }^{\dagger 1,2}$, Michael C Jewett ${ }^{\dagger 1,4}$, Pascale Daran-Lapujade ${ }^{3}$, \\ Roberta Mustacchi ${ }^{1}$, Renata Usaite ${ }^{1}$, Jack T Pronk ${ }^{3}$, Christopher T Workman ${ }^{2}$ \\ and Jens Nielsen*1,5
}

Address: ${ }^{1}$ Center for Microbial Biotechnology, Department of Systems Biology, Technical University of Denmark, Building 223, DK-2800, Kgs. Lyngby, Denmark, ${ }^{2}$ Center for Biological Sequence Analysis, Department of Systems Biology, Technical University of Denmark, Building 208, DK2800 Kgs. Lyngby, Denmark, ${ }^{3}$ Kluyver Centre for Genomics of Industrial Fermentation and Department of Biotechnology, Delft University of Technology, Julianalaan 67, 2628 BC, Delft, The Netherlands, ${ }^{4}$ Department of Genetics, Harvard Medical School, Boston, MA 02115, USA and ${ }^{5}$ Department of Chemical and Biological Engineering, Chalmers University of Technology, SE- 412 96, Gothenburg, Sweden

Email: Alessandro Fazio - alfa@cbs.dtu.dk; Michael C Jewett - mcjewett@genetics.med.harvard.edu; Pascale Daran-Lapujade - P.A.S.DaranLapujade@tudelft.nl; Roberta Mustacchi - rm@bio.dtu.dk; Renata Usaite - ru@bio.dtu.dk; Jack T Pronk - J.T.Pronk@tudelft.nl;

ChristopherT Workman - workman@cbs.dtu.dk; Jens Nielsen* - nielsenj@chalmers.se

* Corresponding author †Equal contributors

Published: 18 July 2008

BMC Genomics 2008, 9:34I doi:10.1|86/|47|-2|64-9-34|
Received: 28 April 2008

Accepted: 18 July 2008

This article is available from: http://www.biomedcentral.com/l47|-2164/9/34 I

(C) 2008 Fazio et al; licensee BioMed Central Ltd.

This is an Open Access article distributed under the terms of the Creative Commons Attribution License (http://creativecommons.org/licenses/by/2.0), which permits unrestricted use, distribution, and reproduction in any medium, provided the original work is properly cited.

\begin{abstract}
Background: Characterization of cellular growth is central to understanding living systems. Here, we applied a three-factor design to study the relationship between specific growth rate and genome-wide gene expression in 36 steady-state chemostat cultures of Saccharomyces cerevisiae. The three factors we considered were specific growth rate, nutrient limitation, and oxygen availability.
\end{abstract}

Results: We identified 268 growth rate dependent genes, independent of nutrient limitation and oxygen availability. The transcriptional response was used to identify key areas in metabolism around which mRNA expression changes are significantly associated. Among key metabolic pathways, this analysis revealed de novo synthesis of pyrimidine ribonucleotides and ATP producing and consuming reactions at fast cellular growth. By scoring the significance of overlap between growth rate dependent genes and known transcription factor target sets, transcription factors that coordinate balanced growth were also identified. Our analysis shows that Fhl, Rapl, and Sfpl, regulating protein biosynthesis, have significantly enriched target sets for genes up-regulated with increasing growth rate. Cell cycle regulators, such as Ace2 and Swi6, and stress response regulators, such as Yapl, were also shown to have significantly enriched target sets.

Conclusion: Our work, which is the first genome-wide gene expression study to investigate specific growth rate and consider the impact of oxygen availability, provides a more conservative estimate of growth rate dependent genes than previously reported. We also provide a global view of how a small set of transcription factors, $I 3$ in total, contribute to control of cellular growth rate. We anticipate that multi-factorial designs will play an increasing role in elucidating cellular regulation. 


\section{Background}

Regulation of cell growth is of crucial importance for the survival of all living cells. Much effort, therefore, has focused on understanding the mechanisms that control how cells achieve balanced growth, e.g. control of the cell cycle and biosynthesis of cellular building blocks. To date, DNA microarray technology $[1,2]$ has had a considerable impact in defining causal relationships between different growth conditions and the transcriptional response of cells. A number of previous studies in S. cerevisiae have focused on the genome-wide transcriptional response of cells to nutrient limitation [3-5], oxygen availability [6-8] and growth rate (Table 1).

To identify growth rate dependent genes, two major requirements must be met. First, the specific growth rate of the culture $\left(\mathrm{h}^{-1}\right)$ must be controlled. This is necessary to eliminate variability that is inherent in dynamic batch cultivation [7,9-11]. The general approach for obtaining constant specific growth rate is through continuous i.e. chemostat cultivation. Here the specific growth rate is kept constant by continuously feeding a culture with fresh nutrients having one limiting reagent at a specific dilution rate $(D)$. The dilution rate is adjusted to obtain different specific growth rates. Second, it is also important to measure gene expression patterns over a range of specific growth rates. By studying factors in addition to specific growth rate (e.g. nutrient limitation), growth rate dependent genes that are independent of environmental factors can be identified.

Previous works have suggested that growth rate has a tremendous influence on the yeast transcriptional program. Specifically, Regenberg et al. [12] described more than 2400 growth rate dependent genes and proposed a role for the chromosomal location in the regulation of these genes. Castrillo et al. [13] adopted a systems biology approach to investigate the effect of growth rate at the transcriptome, proteome and metabolome levels. They identified about 900 genes whose expression is growth regulated and concentrated, in particular, on the role of the TOR complex 1. More recently, Brauer et al. [14] determined that transcript levels of more than one quarter of all yeast genes are linearly correlated with growth rate. While growth rate dependent genes have been identified from single factor studies [12] and two factor designs, such as growth rate and nutrient limitation $[13,14]$, multifactor designs, such as the approach presented here, are expected to identify growth rate dependent genes that are more independent of the specific growth conditions.

Here we carried out a three factor design to dissect the role of growth rate on the transcriptional program of yeast. The three factors were specific growth rate, nutrient limitation (carbon/nitrogen limitation), and oxygen availability. For the specific growth rate, multiple levels, i.e. $0.03,0.1$ and $0.2 \mathrm{~h}^{-1}$ were evaluated. In the context of growth rate studies, the effect of oxygen availability has not yet been considered. Beyond identifying growth rate dependent genes independent of nutrient limitation and oxygen availability, we sought to use recently developed systems biology tools to distinguish transcription factors (TFs) that may coordinate and regulate the processes that control cellular growth (e.g. cell cycle period, protein biosynthesis, and energy metabolism).

\section{Results and discussion}

A three-factor design to investigate growth rate dependent genes

To study the growth-rate related transcriptional response in $S$. cerevisiae CEN.PK113-7D, we applied a systems approach that integrated transcriptome measurements

Table I: Studies of growth rate effect on transcriptional response in Saccharomyces cerevisiae

\begin{tabular}{|c|c|c|c|c|c|c|}
\hline Study & Strain & Cultivation Mode & Limiting Nutrient ${ }^{a}$ & $\mathrm{O}_{2}$ Availability & $D\left(h^{-1}\right)$ & Array type \\
\hline Hayes et al. (2002) & FY1679b & Batch/Chemostat & $\mathrm{C} / \mathrm{N}$ & Aerobic & $0.1-0.2$ & $\begin{array}{c}\text { Membrane/Glass } \\
\text { slide }\end{array}$ \\
\hline Pir et al. (2006) & BY4743c & Chemostat & $\mathrm{C} / \mathrm{N}$ & Aerobic & $0.1-0.2$ & $\begin{array}{l}\text { Affymetrix Yeast } \\
\text { S98 GeneChip }\end{array}$ \\
\hline $\begin{array}{c}\text { Regenberg et al. } \\
(2006)\end{array}$ & CEN.PKII3-7Dd & Chemostat & C & Aerobic & $\begin{array}{c}0.02-0.05-0.1-0.2- \\
0.25-0.33\end{array}$ & $\begin{array}{l}\text { Affymetrix Yeast } \\
\text { S98 GeneChip }\end{array}$ \\
\hline $\begin{array}{c}\text { Castrillo et al. } \\
\text { (2007) }\end{array}$ & FYI679b & Chemostat & $\mathrm{C} / \mathrm{N} / \mathrm{P} / \mathrm{S}$ & Aerobic & $0.07-0.1-0.2$ & $\begin{array}{l}\text { Affymetrix Yeast } \\
\text { S98 GeneChip }\end{array}$ \\
\hline Brauer et al. (2008) & $\begin{array}{l}\text { DBY } 10085^{d} \\
\text { DBY9492 } \\
\text { DBY9497d }\end{array}$ & Chemostat & $\mathrm{C} / \mathrm{N} / \mathrm{P} / \mathrm{S} / \mathrm{U} / \mathrm{L}$ & Aerobic & $\begin{array}{c}0.05-0.1-0.15-0.2- \\
0.25-0.3\end{array}$ & $\begin{array}{c}\text { Agilent Yeast V2 } \\
(\text { Суз/Су5) }\end{array}$ \\
\hline This Study & CEN.PKII3-7Dd & Chemostat & $\mathrm{C} / \mathrm{N}$ & Aerobic/Anaerobic & $0.03-0.1-0.2$ & $\begin{array}{l}\text { Affymetrix Yeast } \\
\text { S98 GeneChip }\end{array}$ \\
\hline
\end{tabular}

a $C$, carbon; $N$, nitrogen; $P$, phosphorus; $S$, sulfur; $U$, uracil; L, leucine

b Isogenic to S288C

c S288C-derived

d CEN.PK-derived 
with data from protein-DNA interaction networks. A $2 \times 2$ $\times 3$ factorial design was pursued resulting in 12 different growth conditions (Fig. 1), which have been investigated in triplicate. Specifically, steady-state conditions were chosen to perturb (a) specific growth rate (equal to the dilution rate $D$ ), (b) nutrient limitation, and (c) oxygen availability. Each factor comprised at least two levels: (a) $D=0.03 / 0.1 / 0.2 \mathrm{~h}^{-1}$, (b) carbon/nitrogen limitation, and (c) aerobiosis/anaerobiosis. Because the specific growth rate $(\mu)$ equals the dilution rate $(D)$ in our chemostat experiments, the selected range covers cell doubling time $\left(\mathrm{T}_{2}\right)$ between 3.5 and $23.1 \mathrm{~h}\left(\mathrm{~T}_{2}=\ln (2) / \mu\right)$.

We first collected genome-wide transcription profiles from each steady-state using the Affymetrix GeneChip platform. To reduce data dimensionality and explore the data structure, Principal Components Analysis (PCA) was applied to the normalized microarray data (Fig. 2). Three main principal components were observed, comprising $69 \%$ of the variance (see Additional file 1). Strikingly, the PCA projections revealed that the three main principal components segregate the data along the three factors of our factorial design. The factor giving the greatest variance was oxygen availability (O-A split along PC1). The second largest source of variability was observed for nutrient limitation (C-N split along PC2), followed by dilution rate (growth rate split along PC3; Fig. 2A-C). While PC1 shows a clear separation between aerobic and anaerobic conditions, PC2 only distinctly separates the carbon and nitrogen limited conditions for the aerobic case. This is

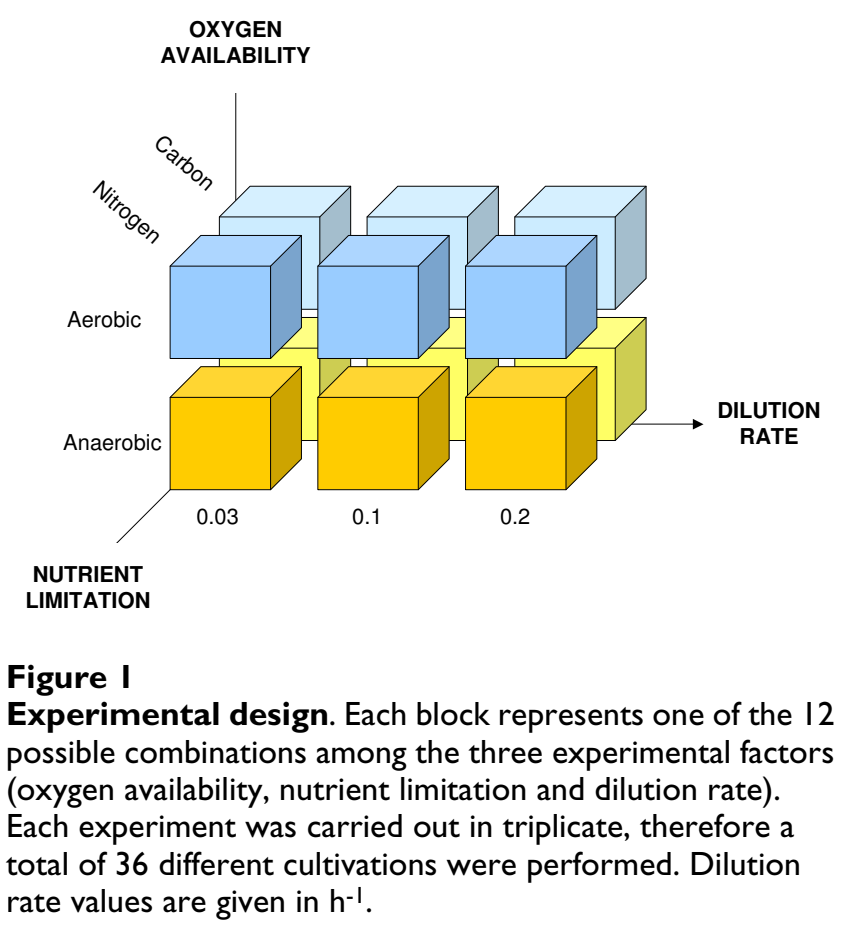

probably due to the fact that in the absence of oxygen only fermentative metabolism is possible, while both respirofermentative (N-limitation) and fully respiratory (C-limitation) metabolism may occur in aerobic conditions. The third factor, specific growth rate, also shows good groupings, although not as distinct as for the other factors (Fig. $2 \mathrm{~B}-\mathrm{D})$. This is consistent with the transcriptome data from Castrillo et al. [13], in which C-limited cultivations were strongly segregated from the other nutrient limited conditions. Notably, the high reproducibility of the replicates demonstrates the quality of our data.

\section{Functional analysis of the $\mathbf{2 6 8}$ growth rate dependent genes}

To quantitatively reveal which genes had significantly changed expression, MicroArray Analysis of Variance (MAANOVA) was carried out by using mixed-model and Fs test (see Methods and Additional file 2). This test permitted the discovery of genes showing significant transcriptional changes with respect to each considered factor (specific growth rate, nutrient limitation and oxygen availability). Table 2 shows the number of differently expressed genes for each of the three factors at different cut-off $q$-values. At a false discovery rate (FDR) of $2 \%$, which was selected for further analysis, a total of 268 growth rate dependent genes were identified as significantly changed. To group genes with common expression profiles over the dilution rate range, the selected gene lists were clustered using hierarchical clustering (Fig. 3). Of the 268 significantly changed genes, 114 genes were up-regulated with increasing growth rate and 154 genes were down-regulated with increasing growth rate (see Additional file 3 ). The significantly changed genes are linearly correlated (either negatively or positively) with increasing growth rate (see Additional file 1). Consistent with the PCA analysis, the factor showing the most prominent segregation was oxygen availability. It is possible that this result, in part, reflects the distribution of experimental effort (see Methods).

To determine significantly enriched Gene Ontology (GO) process terms within the up-regulated and down-regulated growth rate dependent gene clusters, we used the Saccharomyces Genome Database (SGD)-GO tools (significance at $\mathrm{P} \leq 0.01$; see Additional file 3 ). Among genes up-regulated with increasing growth rate, biosynthetic processes were the most significantly enriched (Table 3 ). In particular, genes involved in ribosome biogenesis and assembly, translation, and protein biosynthesis were overrepresented. Nearly half of the up-regulated genes (53/ 114) encoded for components of the ribosome complex. These results suggest that faster growing cells build biomass more efficiently and are consistent with previous reports [12-15]. 

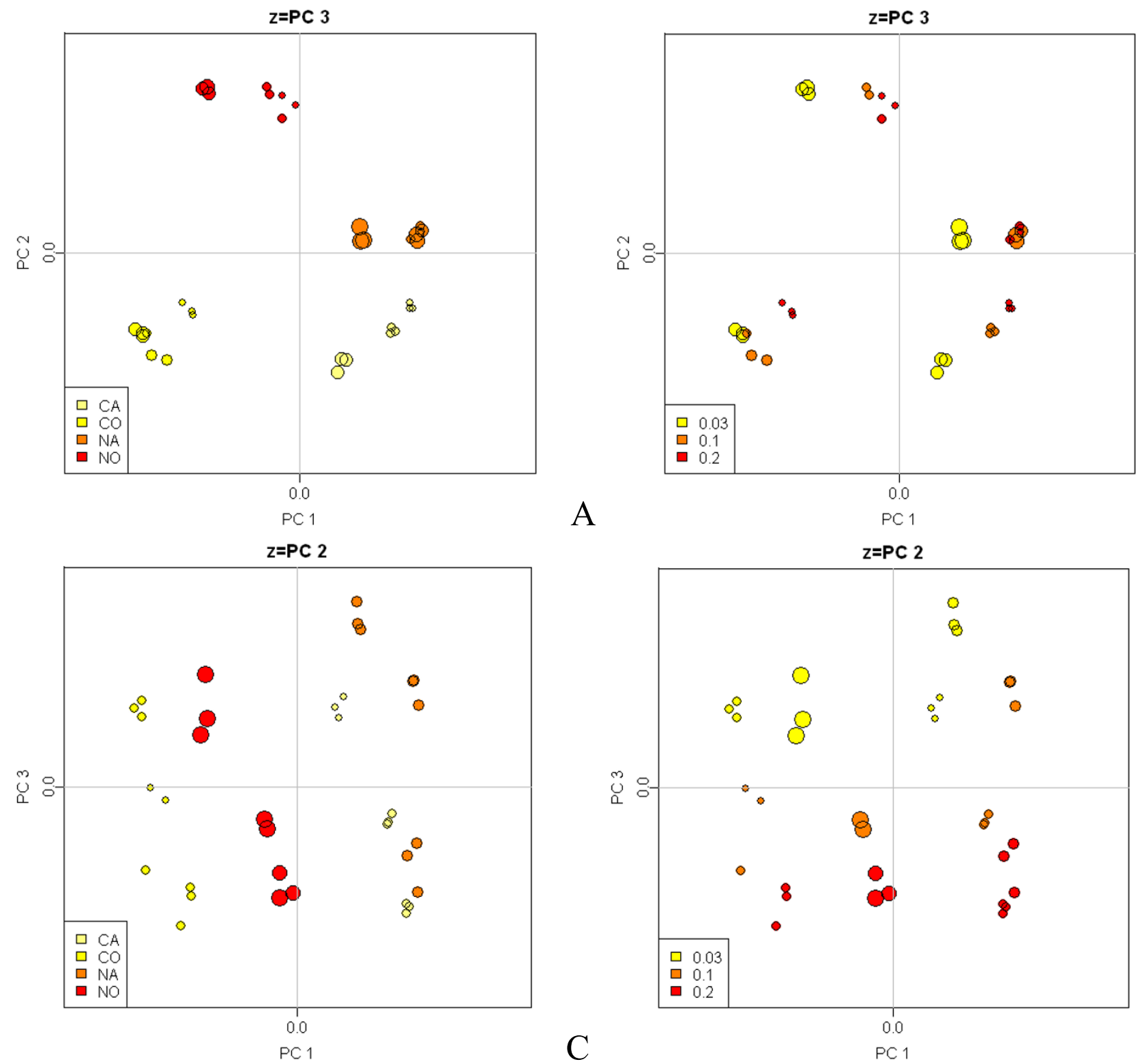

B

Figure 2

PCA projection of samples in the first 3 PC dimensions. Plots A and B show PC dimensions I versus 2 as the $x-$ and $y$ axis and spot size as PC3 in the z-axis. Plots $C$ and D show PCI vs PC3 and highlight the segregation due to the dilution rate factor in PC3. Color in A and $\mathrm{C}$ represents a different combination of these two factors: NO, aerobic nitrogen-limited culture; $\mathrm{CO}$, aerobic carbon-limited culture; NA, anaerobic nitrogen-limited culture; CA, anaerobic carbon-limited culture. Colors in B and $D$ show the dilution rates $0.03,0.1$ and $0.2 \mathrm{~h}^{-1}$.

Among the 154 down-regulated genes, the most over-represented GO terms were response to stress, carbohydrate metabolic process, and catabolic process (Table 3). More specifically, genes encoding proteins involved in ER associated protein catabolism (HRD3), vacuole homeostasis (FAB1, GGA1), ubiquitin cycle (APC9, RTT101, UBC8) and ubiquitin-dependent protein catabolism (MET30, RPN4, RPN14, YFL006W) show lower expression levels at higher specific growth rates. RPN4, for example, regulates cellular levels of the proteasome [16,17]. While gene expression required for protein synthesis increases with increasing growth rate, gene expression required for protein degradation decreases. It is tempting to speculate that increased protein degradation processes at lower growth rates, typically under sub-optimal conditions, is a survival mechanism designed to more efficiently re-use possible resources. 


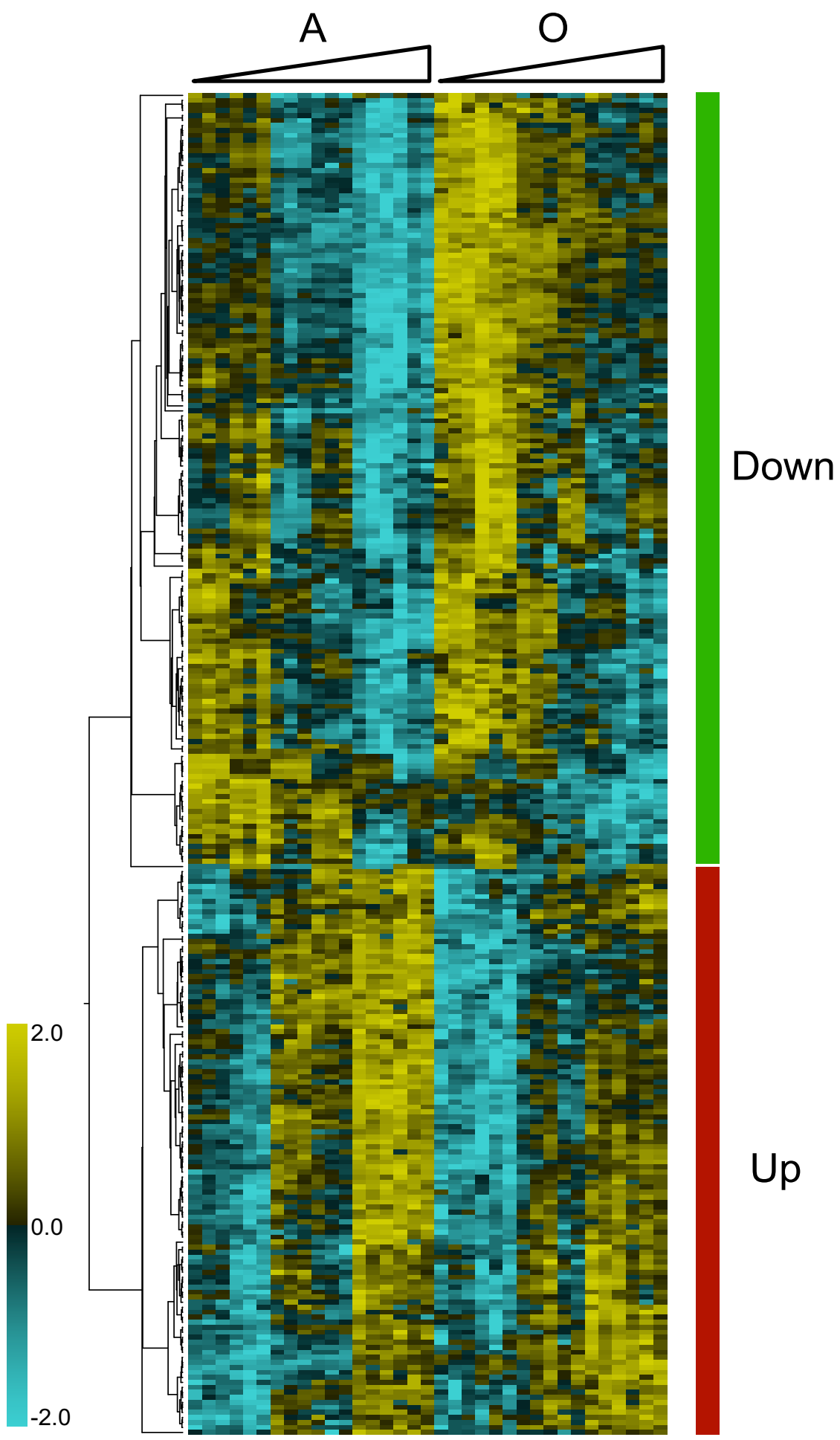

Figure 3

Hierarchical clustering of growth rate dependent genes. The columns represent the experiments and the left hand side of the cluster refers to the anaerobic $(A)$ dataset, while the right hand side to the aerobic $(O)$ dataset. The columns are ordered at increasing dilution rate values $\left(0.03-0.1-0.2 \mathrm{~h}^{-1}\right)$, as indicated by the triangles at the top of the clusters. The rows represent the 268 growth rate dependent genes and the two main clusters of up- and down-regulated genes with increasing $D$ are shown. The scale of the color bar is based on z-score. 
Table 2: The number of significantly changed genes (MAANOVA analysis) at different $q$-value threshold values

\begin{tabular}{lccccc}
\hline q-value threshold & 0.01 & 0.02 & 0.03 & 0.04 & 0.05 \\
\hline Dilution rate & 0 & 268 & 494 & 720 & 938 \\
Nutrient limitation & 373 & 504 & 579 & 642 & 698 \\
Oxygen availability & 1208 & 1933 & 2038 & 2355 & 2594 \\
\hline
\end{tabular}

Strikingly, $11 \%$ of down-regulated genes have kinase activity (only $2.8 \%$ of yeast genes have kinase activity according to SGD), suggesting a possible role for phosphorylation in regulating the growth rate response. In addition, down-regulated genes having an unknown biological process $(22.7 \%)$ or function $(35.1 \%)$ were overrepresented. The lack of annotation may be a result of these genes being expressed weakly under the rapid growth conditions used in most microarray experiments [12].

To identify metabolites in yeast around which mRNA expression changes are significantly associated, we applied the Reporter Metabolite Algorithm [18] (see Methods). The most significant Reporter Metabolites are listed in Table 4. These metabolites participate in diverse metabolic pathways from nucleotide and amino acid metabolism, to phospholipid synthesis and the pentose phosphate pathway. Orotate, for example, is involved in the de novo synthesis of pyrimidine ribonucleotides. A closer look revealed that URA5, whose gene product catalyzes orotate phosphoribosyl transferase, was among the significantly up-regulated genes with increasing growth rate. URA5 is not regulated by pathway intermediates and our analysis suggests that transcriptional control of this critical enzyme involved in DNA synthesis helps to mobilize resources necessary for growth. It is striking that ATP, which participates in more reactions than any other metabolite [19], is among the most significant Reporter Metabolites. This result suggests that gene expression of enzymes involved in ATP production and consumption reactions is significantly regulated over changes in specific growth rate. In summary, the Reporter Metabolite results highlight the broad impact that growth rate has across metabolism.

\section{Transcription factor control of growth rate dependent genes}

To identify and score TFs that might regulate the processes that control cell growth, we scored the significance of overlap between the 268 growth rate dependent genes and

Table 3: GO annotation based on the Biological Process ontology for growth rate dependent genes

\begin{tabular}{|c|c|c|c|}
\hline GO Term & Gene hits & Cluster frequency & $P$-value \\
\hline \multicolumn{4}{|l|}{ Up-regulated Genes (I I4) } \\
\hline cellular biosynthetic process & 61 & $53.5 \%$ & $1.58 \mathrm{E}-2 \mid$ \\
\hline translation & 51 & $44.7 \%$ & 8.27E-2I \\
\hline biosynthetic process & 66 & $57.9 \%$ & I.6IE-20 \\
\hline macromolecule biosynthetic process & 55 & $48.2 \%$ & $4.28 \mathrm{E}-19$ \\
\hline cellular protein metabolic process & 59 & $51.8 \%$ & $3.95 \mathrm{E}-\mathrm{II}$ \\
\hline protein metabolic process & 60 & $52.6 \%$ & 4.IIE-II \\
\hline cellular macromolecule metabolic process & 60 & $52.6 \%$ & $4.78 \mathrm{E}-\mathrm{II}$ \\
\hline primary metabolic process & 90 & $78.9 \%$ & 7.37E-II \\
\hline gene expression & 62 & $54.4 \%$ & $1.29 \mathrm{E}-10$ \\
\hline cellular metabolic process & 91 & $79.8 \%$ & 4.39E-10 \\
\hline metabolic process & 92 & $80.7 \%$ & $9.58 \mathrm{E}-10$ \\
\hline cellular process & 101 & $88.6 \%$ & $8.12 \mathrm{E}-07$ \\
\hline macromolecule metabolic process & 77 & $67.5 \%$ & $8.86 \mathrm{E}-07$ \\
\hline ribosome biogenesis and assembly & 21 & $18.4 \%$ & 4.20E-04 \\
\hline ribosomal subunit assembly & 8 & $7.0 \%$ & $6.90 \mathrm{E}-04$ \\
\hline ribosome assembly & 8 & $7.0 \%$ & $2.82 \mathrm{E}-03$ \\
\hline ribonucleoprotein complex biogenesis and assembly & 21 & $18.4 \%$ & $5.59 \mathrm{E}-03$ \\
\hline \multicolumn{4}{|l|}{ Down-regulated Genes (154) } \\
\hline cellular carbohydrate metabolic process & 18 & $11.8 \%$ & $2.90 \mathrm{E}-04$ \\
\hline carbohydrate metabolic process & 18 & $11.8 \%$ & I.14E-03 \\
\hline macromolecule catabolic process & 22 & $14.4 \%$ & $1.86 \mathrm{E}-03$ \\
\hline response to stress & 26 & $17.0 \%$ & $6.33 \mathrm{E}-03$ \\
\hline catabolic process & 24 & $15.7 \%$ & $9.30 \mathrm{E}-03$ \\
\hline energy reserve metabolic process & 7 & $4.6 \%$ & $9.34 \mathrm{E}-03$ \\
\hline
\end{tabular}

Gene hits indicate the number of genes in the clusters of up-/down-regulated genes belonging to that particular GO term; the value is also given as percentage (cluster frequency). $P$-values are provided as a score of significance (cut-off $\leq 0.0 \mathrm{I}$ ). 
Table 4: Reporter Metabolite analysis

\begin{tabular}{|c|c|c|}
\hline Reporter Metabolites & Number of neighbors & $P$-value \\
\hline Orotate & 3 & 7. $10 \mathrm{E}-04$ \\
\hline D-Mannose 6-phosphate & 5 & $9.7 \mathrm{IE}-04$ \\
\hline Spermidine & 3 & $1.68 \mathrm{E}-03$ \\
\hline alpha, alpha-Trehalose & 4 & $3.30 \mathrm{E}-03$ \\
\hline 5-Phospho-alpha-D-ribose I-diphosphate & 17 & $5.15 E-03$ \\
\hline I-(5'-Phosphoribosyl)-5-amino-4-imidazolecarboxamide & 4 & $5.22 \mathrm{E}-03$ \\
\hline D-Ribose 5-phosphate & 18 & $7.42 \mathrm{E}-03$ \\
\hline Dolichyl beta-D-mannosyl phosphate & 7 & 7.60E-03 \\
\hline FAD & 2 & $9.45 \mathrm{E}-03$ \\
\hline I-Phosphatidyl-D-myo-inositol 4,5-bisphosphate & 3 & $9.99 \mathrm{E}-03$ \\
\hline beta-D-Glucose & 3 & I.00E-02 \\
\hline ATP & 113 & $1.02 \mathrm{E}-02$ \\
\hline 5'-Methylthioadenosine & 2 & $1.05 \mathrm{E}-02$ \\
\hline alpha-D-Glucose 6-phosphate & 11 & I.19E-02 \\
\hline O-Phospho-4-hydroxy-L-threonine & 2 & I.26E-02 \\
\hline N6-(L-I,3-Dicarboxypropyl)-L-lysine & 2 & $1.37 \mathrm{E}-02$ \\
\hline Glycogen & 4 & $1.42 \mathrm{E}-02$ \\
\hline Urea-I-carboxylate & i & $1.69 \mathrm{E}-02$ \\
\hline (S)-Dihydroorotate & 2 & I.75E-02 \\
\hline 2-Phenylacetamide & I & I.82E-02 \\
\hline Phenylacetic acid & I & $1.82 \mathrm{E}-02$ \\
\hline Indole-3-acetamide & I & $1.82 \mathrm{E}-02$ \\
\hline Indole-3-acetate & I & $\mathrm{I} .82 \mathrm{E}-02$ \\
\hline (S)-I-Pyrroline-5-carboxylate & i & $1.82 \mathrm{E}-02$ \\
\hline L-I-Pyrroline-3-hydroxy-5-carboxylate & I & $1.82 \mathrm{E}-02$ \\
\hline trans-4-Hydroxy-L-proline & I & $1.82 \mathrm{E}-02$ \\
\hline
\end{tabular}

Reporter Metabolite analysis [18] identifies metabolites around which the most significant transcriptional changes occur. The number of neighbors indicates the number of genes whose products catalyze a reaction involving that particular metabolite. The algorithm took as input the MAANOVA analysis referring to dilution rate effect. The $P$-value gives a measure of significance and all results $<0.02$ are reported.

known TF target sets [20,21] (Table 5, hypergeometric test at $\mathrm{P}<0.01)$. In total, this analysis revealed 13 TFs having significantly enriched target sets (Fig. 4) for genes up-regulated with increasing growth rate. Fhl1, Rap1, Sfp1, and Yap5 are involved in regulating ribosomal protein gene expression. Ace2 and Swi6 participate in cell cycle regulation. Yap1, Yap6, Smp1, and Pdr1 are involved in stress response and signaling. Bas1 is involved in amino acid and nucleotide biosynthesis, while Stb4 and Gat3 have unclear roles. The connectivity of TFs with enriched targets demonstrates how the global response of growth rate dependent genes may be controlled (Fig. 4). Sin4, Rap1, Swi6, and Swi4 appear to coordinate the response by linking protein synthesis, the cell cycle, and the stress response. No significant TFs were found when the same TF analysis was performed for the down-regulated genes.

Fhl1, Rap1, and Sfp1 were the TFs with the greatest enrichment of growth-rate dependent target genes (Table 5). These TFs are all involved in ribosomal protein (RP) gene transcription. There are $138 \mathrm{RP}$ genes in yeast, and their expression accounts for more than $50 \%$ of the RNA pol II dependent transcription [22]. Rap1 participates in ribosomal gene expression [23-25] and is involved in moving nucleosomes from a certain region of chromatin in order to allow Fhl1 and Ifh 1 to trigger RP gene transcription [26-29].

Ace2 and Swi6 are known cell cycle regulators [30] and our TF enrichment analysis suggests a role for these two TFs in controlling growth rate, which remains a hypothesis. Swi6 is part of the two heterodimeric transcriptional regulators SBF (Swi4/Swi6) and MBF (Mbp1/Swi6) [31], that act in the early cell cycle (G1 phase). Ace2, instead, plays an important role during the $\mathrm{M}$ phase. Previously, the effect of Ace 2 on the length of G1 phase has been reported by Laabs et al. [32], who demonstrated that a G1 specific delay in yeast daughter cells is due to this TF. Little is known about Stb4 (SGD classifies Stb4 as having an unknown biological process): it binds to Swi5 [33] and a two-hybrid screen [34] found that it binds to Sin3. We hypothesize that identification of Stb4 as a principal regulating TF in our study, and the close association of it with Swi6 and Ace 2 (Fig. 4), may hint at a possible role for Stb4 in regulating the cell cycle.

Highlighting the importance of both protein biosynthesis and cell cycle progression in controlling growth rate, Sfp1 was also identified in the TF enrichment analysis. Jorgensen $e$ al. [35] suggested that Sfp1 activates RP gene 
Table 5: Transcription factor target set enrichment results

\begin{tabular}{|c|c|c|c|c|c|}
\hline TFs & $\log 10$ (p-value) & Overlap & Set 1 & Set2 & Background \\
\hline \multicolumn{6}{|c|}{ Harbison et al. (YPD), $\mathrm{p}<0.01$} \\
\hline $\mathrm{FHLI}$ & -28.44 & 42 & 114 & 213 & 5636 \\
\hline RAPI & -16.52 & 42 & 114 & 414 & 5636 \\
\hline GAT3 & -9.68 & 23 & 114 & 179 & 5636 \\
\hline SMPI & -4.45 & 17 & 114 & 180 & 5636 \\
\hline YAP5 & -4.1 & 16 & 114 & 168 & 5636 \\
\hline PDRI & -3.48 & 15 & 114 & 164 & 5636 \\
\hline \multicolumn{6}{|c|}{ Harbison et al. (Other), $\mathrm{p}<0.01$} \\
\hline FHLI (rapa) & -27.96 & 42 & 114 & 220 & 5636 \\
\hline FHLI (sm) & -24.83 & 44 & 114 & 294 & 5636 \\
\hline FHLI $\left(\mathrm{H}_{2} \mathrm{O}_{2}-\mathrm{Hi}\right)$ & -16.35 & 30 & 114 & 189 & 5636 \\
\hline RAPI (sm) & -13.11 & 37 & 114 & 392 & 5636 \\
\hline SFPI (sm) & -8.44 & 18 & 114 & 118 & 5636 \\
\hline \multicolumn{6}{|c|}{ Beyer et al. SLL > 4} \\
\hline FHLI & -27.43 & 51 & 114 & 379 & 5636 \\
\hline RAPI & -20.29 & 34 & 114 & 196 & 5636 \\
\hline SFPI & -18.9 & 28 & 114 & 129 & 5636 \\
\hline STB4 & $-|7.9|$ & 29 & 114 & 153 & 5636 \\
\hline SWI6 & -16 & 42 & 114 & 430 & 5636 \\
\hline YAP6 & -15.16 & 32 & 114 & 242 & 5636 \\
\hline YAPI & -14.47 & 35 & 114 & 314 & 5636 \\
\hline ACE2 & -10.97 & 32 & 114 & 335 & 5636 \\
\hline BASI & -10.64 & 22 & 114 & 147 & 5636 \\
\hline
\end{tabular}

Target sets defined by Harbison et al. [2I] chlP-chip study. p-values < 0.01 for YPD and other growth conditions are indicated (rapa: rapamycin, sm: sulfometuron methyl, $\mathrm{H}_{2} \mathrm{O}_{2}-\mathrm{Hi}$, hydrogen peroxide $4 \mathrm{mM}$ ). Sets were also analyzed for Beyer et al. [20] derived target sets using sum of loglikelihood (SSL) $>4$.

transcription by influencing the nuclear localization of Fhl1 and Ifh1. The TOR and PKA pathways, previously identified [13] as critical in controlling growth rate, participate in keeping Sfp1 in the nucleus [36]. Sfp1 also modulates cell cycle progression in the late G1 phase (Start) by controlling cell size in eukaryotic cells $[37,38]$. Cell cycle progression in the late G1 phase (Start) is dependent on the attainment of a critical cell size and critical translation rate [39].

Several identified TFs with significantly enriched targets are primarily involved in the stress response. Yap1 regulates the expression of oxidative stress response genes [40]. Chua et al. [41] have indicated that Yap1 overexpression induces genes involved in translation and tRNA metabolism. Yap6 is known to have a role in salt tolerance [42] and recently Steinfeld et al. [43] have indicated a role in regulation of sugar transport. Pdr1 is a zinc finger transcription factor whose target genes carry out ABC transport, other transport, and membrane lipid and cell wall biosyntheses [44]. We have previously proposed a role for Pdr1 in DNA damage response process and showed that Yap5 and Swi5 targets overlap significantly with Pdr1 targets in absence of the damaging agent [45].
In summary, the Reporter Metabolite and TF enrichment analyses both support the conclusion that in yeast changes in growth rates are associated with the regulation of protein synthesis, the cell cycle, and the stress response. For example, four TFs involved in regulation of protein synthesis genes are identified. In agreement, the Reporter Metabolite analysis identifies ATP. Thus, genes encoding products that catalyze reactions involving ATP, and one of the most energy intensive processes of the cell, are observed as being significantly changed. In addition, identification of cell cycle regulators is consistent with results from Reporter Metabolite analysis suggesting that regulation of metabolic pathways of DNA synthesis (the de novo synthesis of pyrimidine ribonucleotides) have significant transcriptional changes.

\section{Comparison with previous growth rate studies}

Compared with earlier studies on the influence of the specific growth rate on global transcription, our analysis provides a much more moderate estimate of the number of growth rate dependent genes. This is likely due to two main reasons. First, the three-factor design employed here de-emphasizes genes that might be significant when oxygen availability is not considered. Second, the statistical methods and significance thresholds among the studies 


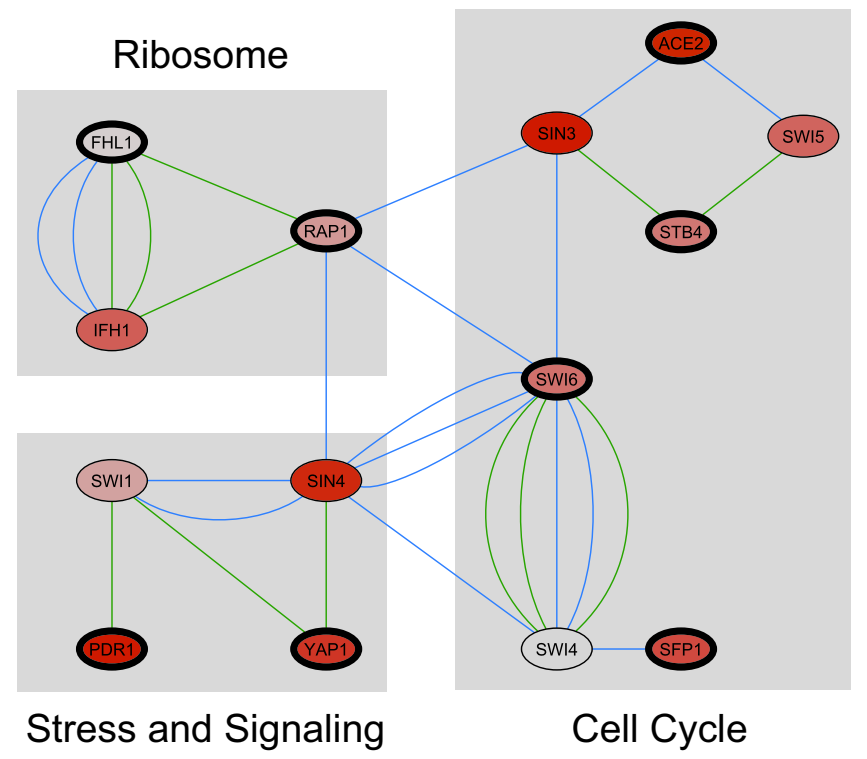

\section{Figure 4}

Network of TFs regulating the genes up-regulated with increasing dilution rate. Nodes with thicker outlines contain the TFs found in our analysis (YAP5, YAP6, SMPI, GAT3 and BASI do not map into this network). The connectivity among nodes is based on the interactions stored at BioGRID database [58] and the interaction types can be divided in two groups: (I) genetic interactions, which can be detected by dosage rescue, synthetic rescue, synthetic growth defect, synthetic lethality, phenotypic enhancement and phenotypic suppression (blue edges); and (2) protein interaction, detected by affinity capture-MS, affinity capturewestern, reconstituted complex and two-hybrid (green edges). See Additional file 3 for details about these interactions. Moreover, nodes are colored according to the expression levels of the genes encoding the TFs and a grey-red scale is used (red color indicates higher expression levels). In this network, the TF expression values from experiments at 0.2 $\mathrm{h}^{-1}$ are depicted. No significant differences in TF expression values were observed at different dilution rates (see Additional file I). The network was drawn by using Cytoscape [59].

are different. Our previous study [12], for example, found the largest number of growth rate dependent genes ( 2400). However, that study used a newly developed consensus clustering algorithm to group similar genes that correlated with growth rate [46]. As another illustration, Castrillo et al. [13] identified about 900 growth rate dependent genes by performing analysis of covariance (ANCOVA) and applying a $q$-value threshold of $\leq 0.05$ for significance. At this threshold, their results are consistent with our findings ( 978 genes, $q$-value $\leq 0.05$; see Table 2 ). The number of genes specifically overlapping between the work of Castrillo et al. and this study at a $q$-value threshold of 0.05 is 315 . Using our more conservative cut-off, the overlap is 119 .
Given differences between experimental designs and approaches for determining growth rate dependent genes, it is perhaps not surprising that few common genes are observed among our results and the three previous studies (see Additional file 1). Specifically, 21 up-regulated genes and 10 down-regulated genes were shared (Table 6 and 7). Among the common up-regulated genes, 11 were involved in translation (mostly RP genes) and 3 in sphingolipid biosynthesis (FEN1, SUR4, URA7). Of common down-regulated genes, 3 had unknown process (YDR262W, YMR090W, YOL153C) and 4 were involved in regulation of the enzyme fructose-1,6-bisphosphatase, Fbp1 (PFK26, VID28, VID30, YLR345W). Despite only a small overlap of specific genes among studies, significantly enriched GO Biological Process terms identified the same overarching biological changes. Considering the substantial variation between the different studies, our multi-factorial dataset is valuable for obtaining robust answers from queries on the effect of growth on transcription of different genes. Due to our multi-factorial design, our dataset is also valuable for evaluation of e.g. the effect of nutritional state independent of growth rate and oxygen availability.

\section{Conclusion}

By increasing the number of experimental factors, we have identified a more conservative set of growth-rate dependent genes. Specifically, our analysis has identified 268 specific growth rate dependent genes. Results of a gene function analysis were found to be in agreement with previous studies [12-14]. New insight into the regulation of growth rate regulated genes has also been provided. Specifically, 13 TFs have been identified as related to genes whose transcripts level increased with increasing growth rate and 8 of these are connected in a map of regulatory pathways supported by known protein-DNA interactions. Supported by the Reporter Metabolite analysis, the TFs that coordinate growth rate dependent genes are primarily involved in protein synthesis, the cell cycle, and the stress response. Strikingly, down-regulated genes with increasing growth rate did not show common regulation, likely due to the high percentage of uncharacterized genes. We have shown that multi-factor designs, combined with a systems biology approach, can enhance our knowledge about yeast responses to growth rate. This approach will be valuable for studying any other environmental or genetic factor of interest.

\section{Methods}

\section{Strain and chemostat cultivations}

The reference laboratory strain $S$. cerevisiae CEN.PK1137D (MATa) [47] was grown in well controlled 2 liter jacketed chemostats (Braun Biotech and Applikon) with a constant working volume of 1.0 liter. Cultivations were carried out (in triplicates) in aerobic/anaerobic and car- 
Table 6: Common up-regulated genes among growth rate studies

\begin{tabular}{|c|c|c|}
\hline ORF & Gene Name & Description \\
\hline YBL039C & URA7 & $\begin{array}{l}\text { Major CTP synthase isozyme (see also URA8), catalyzes the ATP-dependent transfer of the amide nitrogen from } \\
\text { glutamine to UTP, forming CTP, the final step in de novo biosynthesis of pyrimidines; involved in phospholipid } \\
\text { biosynthesis }\end{array}$ \\
\hline YBRI89W & RPS9B & $\begin{array}{l}\text { Protein component of the small (40S) ribosomal subunit; nearly identical to Rps9Ap and has similarity to E. coli S4 and } \\
\text { rat S9 ribosomal proteins }\end{array}$ \\
\hline YBRI9IW & RPL2IA & $\begin{array}{l}\text { Protein component of the large (60S) ribosomal subunit, nearly identical to Rpl2 IBp and has similarity to rat L2I } \\
\text { ribosomal protein }\end{array}$ \\
\hline YCR034W & FENI & $\begin{array}{l}\text { Fatty acid elongase, involved in sphingolipid biosynthesis; acts on fatty acids of up to } 24 \text { carbons in length; mutations have } \\
\text { regulatory effects on I,3-beta-glucan synthase, vacuolar ATPase, and the secretory pathway }\end{array}$ \\
\hline YDL083C & RPSI6B & $\begin{array}{l}\text { Protein component of the small (40S) ribosomal subunit; identical to Rps I6Ap and has similarity to E. coli S9 and rat S16 } \\
\text { ribosomal proteins }\end{array}$ \\
\hline YDR064W & RPSI3 & Protein component of the small (40S) ribosomal subunit; has similarity to E. coli SI5 and rat SI3 ribosomal proteins \\
\hline YDRI44C & MKC7 & GPI-anchored aspartyl protease (yapsin) involved in protein processing; shares functions with Yap3p and Kex2p \\
\hline YDR32IW & ASPI & Cytosolic L-asparaginase, involved in asparagine catabolism \\
\hline YEL040W & UTR2 & $\begin{array}{l}\text { Cell wall protein that functions in the transfer of chitin to beta(I-6)glucan; putative chitin transglycosidase; } \\
\text { glycosylphosphatidylinositol (GPI)-anchored protein localized to the bud neck; has a role in cell wall maintenance }\end{array}$ \\
\hline YER009W & NTF2 & $\begin{array}{l}\text { Nuclear envelope protein, interacts with GDP-bound Gsplp and with proteins of the nuclear pore to transport Gsplp } \\
\text { into the nucleus where it is an essential player in nucleocytoplasmic transport }\end{array}$ \\
\hline YGL076C & RPL7A & $\begin{array}{l}\text { Protein component of the large (60S) ribosomal subunit, nearly identical to Rpl7Bp and has similarity to E. coli L30 and } \\
\text { rat L7 ribosomal proteins; contains a conserved C-terminal Nucleic acid Binding Domain (NDB2) }\end{array}$ \\
\hline YKL08IW & TEF4 & Translation elongation factor EF-I gamma \\
\hline YLRI86W & EMGI & $\begin{array}{l}\text { Protein required for the maturation of the I8S rRNA and for } 40 \mathrm{~S} \text { ribosome production; associated with spindle/ } \\
\text { microtubules; nuclear localization depends on physical interaction with Nop I4p; may bind snoRNAs }\end{array}$ \\
\hline YLR325C & RPL38 & Protein component of the large (60S) ribosomal subunit, has similarity to rat L38 ribosomal protein \\
\hline YLR372W & SUR4 & $\begin{array}{l}\text { Elongase, involved in fatty acid and sphingolipid biosynthesis; synthesizes very long chain 20-26-carbon fatty acids from } \\
\mathrm{CI} \text {-CoA primers; involved in regulation of sphingolipid biosynthesis }\end{array}$ \\
\hline YML036W & CGII2I & $\begin{array}{l}\text { Protein involved in telomere uncapping and elongation as component of the KEOPS protein complex with Bud32p, } \\
\text { Kaelp, Pcclp, and Gon7p; also shown to be a component of the EKC protein complex; homolog of human CGI-I2I }\end{array}$ \\
\hline YML063W & RPSIB & $\begin{array}{l}\text { Ribosomal protein } 10 \text { ( } r \text { I } 10) \text { of the small }(40 \mathrm{~S}) \text { subunit; nearly identical to Rps I Ap and has similarity to rat S3a ribosomal } \\
\text { protein }\end{array}$ \\
\hline YMR3I8C & $\mathrm{ADH} 6$ & $\begin{array}{l}\text { NADPH-dependent medium chain alcohol dehydrogenase with broad substrate specificity; member of the cinnamyl } \\
\text { family of alcohol dehydrogenases; may be involved in fusel alcohol synthesis or in aldehyde tolerance }\end{array}$ \\
\hline YOL040C & RPSI5 & Protein component of the small (40S) ribosomal subunit; has similarity to E. coli SI9 and rat SI5 ribosomal proteins \\
\hline YOLI20C & RPLI8A & $\begin{array}{l}\text { Protein component of the large (60S) ribosomal subunit, identical to RplI8Bp and has similarity to rat LI8 ribosomal } \\
\text { protein; intron of RPLI8A pre-mRNA forms stem-loop structures that are a target for Rnt Ip cleavage leading to } \\
\text { degradation }\end{array}$ \\
\hline YPLI44W & YPLI44W & $\begin{array}{l}\text { Putative protein of unknown function; green fluorescent protein (GFP)-fusion protein localizes to the cytoplasm; null } \\
\text { mutant is viable, exhibits shortened telomeres }\end{array}$ \\
\hline
\end{tabular}

bon/nitrogen limited conditions, at $30^{\circ} \mathrm{C}$ with a stirrer speed of $800 \mathrm{rpm}, \mathrm{pH}$ of 5.0 (maintained by automatic addition of $2 \mathrm{~N}$ potassium hydroxide) and dilution rates of $0.03,0.1$ and $0.2 \mathrm{~h}^{-1}$. Aerobic conditions were maintained by sparging the cultures with air $\left(1.0 \mathrm{~L} \mathrm{~min}^{-1}\right)$ and the concentration of dissolved oxygen was measured with Mettler Toledo polarographic electrode. Anaerobic conditions were maintained by sparging the medium reservoir and the fermentor with pure nitrogen gas $\left(0.5 \mathrm{~L} \mathrm{~min}^{-1}\right)$. Moreover, oxygen diffusion was minimized by using norprene tubing and butyl septa. The bioreactors were fitted with cooled condensers $\left(2-4^{\circ} \mathrm{C}\right)$ and the off-gas was led to a gas analyzer (INNOVA and NGA 2000 Rosemount) to measure the content of $\mathrm{CO}_{2}$ and $\mathrm{O}_{2}$. Steady-state was reached when at least five residence times had passed since starting the continuous cultivation and carbon dioxide evolution, dry weight measurements, and HPLC measurements of extracellular metabolites were constant.
The experimental work was divided into two efforts. Aerobic cultivations were carried out in the laboratory of Jens Nielsen. Anaerobic cultivations were carried out in the laboratory of Jack T. Pronk. Considerable effort was invested in standardizing the strain, growth conditions, sampling protocols, and analytical procedures. Our groups previously published a report that concluded that microarray experiments in our laboratories were excellently comparable [7]. Triplicate cultivations were carried out for each set of conditions to reduce bias that might unexpectedly arise and to account for biological variance.

\section{Media}

The medium composition was as previously described by Tai et al. [8]. For N-limited cultivations, residual glucose concentration in the chemostat was targeted to $17 \pm 2 \mathrm{~g} \mathrm{~L}^{-}$ 1 . This was to sustain glucose repression at the same level in all cultivations. The mineral medium composition for 
Table 7: Common down-regulated genes among growth rate studies

\begin{tabular}{|c|c|c|}
\hline ORF & Gene Name & Description \\
\hline YOLI53C & YOLI53C & Hypothetical protein \\
\hline YLR345W & YLR345W & $\begin{array}{l}\text { Similar to 6-phosphofructo-2-kinase/fructose-2,6-bisphosphatase enzymes responsible for the metabolism of fructoso- } \\
\text { 2,6-bisphosphate; mRNA expression is repressed by the RfxIp-Tuplp-Ssn6p repressor complex; YLR345W is not an } \\
\text { essential gene }\end{array}$ \\
\hline YGR070W & ROMI & $\begin{array}{l}\text { GDP/GTP exchange protein (GEP) for Rholp; mutations are synthetically lethal with mutations in rom } 2 \text {, which also } \\
\text { encodes a GEP }\end{array}$ \\
\hline YMR090W & YMR090W & $\begin{array}{l}\text { Putative protein of unknown function with similarity to DTDP-glucose 4,6-dehydratases; green fluorescent protein } \\
\text { (GFP)-fusion protein localizes to the cytoplasm; YMR090W is not an essential gene }\end{array}$ \\
\hline YDR262W & YDR262W & $\begin{array}{l}\text { Putative protein of unknown function; green fluorescent protein (GFP)-fusion protein localizes to the vacuole and is } \\
\text { induced in response to the DNA-damaging agent MMS; gene expression increases in response to Zymoliase treatment }\end{array}$ \\
\hline YGLI2IC & GPGI & $\begin{array}{l}\text { Proposed gamma subunit of the heterotrimeric G protein that interacts with the receptor Grplp; involved in regulation } \\
\text { of pseudohyphal growth; requires Gpblp or Gpb2p to interact with Gpa2p }\end{array}$ \\
\hline YILI07C & PFK26 & $\begin{array}{l}\text { 6-phosphofructo-2-kinase, inhibited by phosphoenolpyruvate and sn-glycerol 3-phosphate, has negligible fructose-2,6- } \\
\text { bisphosphatase activity, transcriptional regulation involves protein kinase A }\end{array}$ \\
\hline YGR087C & PDC6 & $\begin{array}{l}\text { Minor isoform of pyruvate decarboxylase, key enzyme in alcoholic fermentation, decarboxylates pyruvate to } \\
\text { acetaldehyde, regulation is glucose- and ethanol-dependent, involved in amino acid catabolism }\end{array}$ \\
\hline YILOI7C & VID28 & $\begin{array}{l}\text { Protein involved in proteasome-dependent catabolite degradation of fructose- I,6-bisphosphatase (FBPase); localized to } \\
\text { the nucleus and the cytoplasm }\end{array}$ \\
\hline YGL227W & VID30 & $\begin{array}{l}\text { Protein involved in proteasome-dependent catabolite degradation of fructose-I,6-bisphosphatase (FBPase); shifts the } \\
\text { balance of nitrogen metabolism toward the production of glutamate; localized to the nucleus and the cytoplasm }\end{array}$ \\
\hline
\end{tabular}

the N-limited cultivations was (amounts per liter): $\left(\mathrm{NH}_{4}\right)_{2} \mathrm{SO}_{4} 1 \mathrm{~g}, \mathrm{KH}_{2} \mathrm{PO}_{4} 3 \mathrm{~g}, \mathrm{~K}_{2} \mathrm{SO}_{4} 5.3 \mathrm{~g}, \mathrm{MgSO}_{4} \cdot 7 \mathrm{H}_{2} \mathrm{O}$ $0.5 \mathrm{~g}$, Trace Metal Solution $1 \mathrm{~mL}$, antifoaming agent 0.05 $\mathrm{mL}$ and vitamin solution $1 \mathrm{~mL}$. The mineral medium composition for the C-limited cultivations was (amounts per liter): $\left(\mathrm{NH}_{4}\right)_{2} \mathrm{SO}_{4} 5 \mathrm{~g}, \mathrm{KH}_{2} \mathrm{PO}_{4} 3 \mathrm{~g}, \mathrm{MgSO}_{4} \cdot 7 \mathrm{H}_{2} \mathrm{O} 0.5$ $\mathrm{g}$, Trace Metal Solution $1 \mathrm{~mL}$, antifoaming agent $0.05 \mathrm{~mL}$ and vitamin solution $1 \mathrm{~mL}$. The inlet glucose concentration was ca. 11 and $25 \mathrm{~g} \mathrm{~L}^{-1}$ for aerobic and anaerobic experiments, respectively. Moreover, anaerobic cultivation medium was supplemented with Tween 80/ergosterol solution $(1.25 \mathrm{~mL} / \mathrm{L})$.

\section{Analytical methods}

The concentration of biomass at steady-state was determined on a dry weight basis by filtering $5 \mathrm{~mL}$ of culture through a pre-weighed $0.45 \mu \mathrm{m}$ nitrocellulose filter (Gelman Sciences, Ann Arbor, MI). The filter was washed with distilled water, dried in a microwave oven at $150 \mathrm{~W}$ for 15 minutes and finally weighed to determine its increase in dry weight. Culture samples $(10 \mathrm{~mL})$ for determination of extracellular glucose, succinate, glycerol, acetate, ethanol and pyruvate concentrations were immediately filtered through a $0.2 \mu \mathrm{m}$ filter (Osmonics, Minnetonka, MN, USA) and the filtrate was stored at $-20^{\circ} \mathrm{C}$ for further analysis. The metabolite concentrations were determined by high pressure liquid chromatography using an Aminex HPX87H column (Biorad) kept at $65^{\circ} \mathrm{C}$ and eluted at 0.6 mL per minute with $\mathrm{H}_{2} \mathrm{SO}_{4}$. Pyruvate was detected spectrophotometrically by a Waters 486 Tunable Absorbance Detector at $210 \mathrm{~nm}$. Glucose, succinate, glycerol, acetate and ethanol were detected by a Waters 410 Differential Refractometer.

\section{RNA sampling and isolation}

Samples for RNA isolation from aerobic cultivations were taken by rapidly sampling $20 \mathrm{~mL}$ of culture into a tube with 35-40 mL of crushed ice in order to decrease the sample temperature to below $2^{\circ} \mathrm{C}$ in less than 10 seconds. Cells were then centrifuged $\left(4500 \mathrm{rpm}\right.$ at $0^{\circ} \mathrm{C}$ for $3 \mathrm{~min}$ utes), instantly frozen in liquid nitrogen and stored at $80^{\circ} \mathrm{C}$ until further use. Sampling for RNA isolations from anaerobic cultivations was performed as described by Piper et al. [7].

Total RNA was extracted using FastRNA Pro RED kit (QBiogene, Inc, USA) according to manufacturer's instructions after partially thawing the samples on ice. RNA sample integrity and quality was assessed prior to hybridization with an Agilent 2100 Bioanalyzer and RNA 6000 Nano LabChip kit.

\section{Probe preparation and hybridization to arrays}

Messenger RNA extraction, cDNA synthesis and labeling, as well as array hybridization to Affymetrix Yeast Genome S98 arrays, were performed as described in the Affymetrix users' manual [48]. Washing and staining of arrays were performed using the GeneChip Fluidics Station 450 and scanning with the Affymetrix GeneArray Scanner.

\section{Microarray gene transcription analysis}

Affymetrix Microarray Suite v5.0 was used to generate CEL files of the scanned DNA microarrays. These CEL files were preprocessed by using gcrma and affy packages $[49,50]$ available in Bioconductor. Raw data was background corrected by using gcrma package and normalized by using qspline method [51]. Probe summarization was 
made using only the perfect match (PM) values and median polish settings [52].

Principal Components Analysis (PCA) was performed in order to elucidate the relative importance of the three factors characterizing our experimental design: oxygen availability, nutrient limitation and dilution rate. To select genes whose expression levels were related to these factors, MicroArray Analysis of Variance (MAANOVA) was performed with a mixed model ANOVA with the fixed factors 'oxygen', 'nutrient' and 'dilution rate' and a single random factor, 'sample', representing the biological replicates [53]. Among the various F-tests, the so called Fs was chosen [54] and the $q$-value method was used to correct for multiple testing [55], which was shown to be less conservative than the FDR methodology described by Benjamini \& Hochberg [56]. The threshold of significance was set at 0.02 for a false discovery rate of $2 \%$. MAANOVA is available as a package in Bioconductor and details of the code are given in Additional file 2. Subsequently, in order to group genes with common expression profiles over the dilution rate range, the selected gene lists were clustered using hierarchical clustering (unweighted pair-group average with a non-centric Pearson correlation based distance) and the Gene Ontology of the generated clusters was investigated [57].

\section{Reporter Metabolite analysis}

Using the entire gene expression data set, we applied the Reporter Metabolite Algorithm [18] with a newly reported genome-scale metabolic model of yeast (Nookaew et al., submitted). More specifically, the genome-scale model was converted to a bipartite undirected graph. In this graph, each metabolite node has as neighbors the enzymes catalyzing the formation and consumption of the metabolite. The transcriptome data were mapped on the enzyme nodes using the significant values of gene expression. The normal cumulative distribution function was used to convert the p-values to a Z-score. Each metabolite was assigned the average score of its $k$ neighboring enzymes, and this score was then corrected for the background by subtracting the mean and dividing by the standard deviation of average scores of 10,000 enzyme groups of size $k$ selected from the same data set. These corrected scores were then converted back to $P$ values by using the normal cumulative distribution function and the most significant metabolites, Reporter Metabolites, were ranked.

\section{Transcription factor enrichment analysis}

For the genes that were found to be differentially transcribed due to growth rate, we investigated if the set of upand/or down-regulated genes were enriched for regulation by specific transcription factors. Definitions of transcription factor target sets (protein-DNA interactions) were derived from two different data sources $[20,21]$ at $p$-value threshold 0.01 for the Harbison et al. study and sum of log-likelihood threshold 4 for the Beyer et al. study. The hypergeometric test was performed for each TF in each of these 2 set definitions versus the up- and down-regulated genes and the resulting $p$-values were Bonferroni adjusted.

\section{Abbreviations}

FDR: False Discovery Rate; GO: Gene Ontology; MAANOVA: MicroArray ANalysis Of Variance; PCA: Principal Components Analysis; RP: Ribosomal Protein; SGD: Saccharomyces Genome Database; TF: Transcription Factor.

\section{Competing interests}

The authors declare that they have no competing interests.

\section{Additional material}

\section{Additional file 1}

Supplementary Figures and Tables. Additional figures and tables about the PCA analysis, consensus cluster analysis and the comparison among the four growth rate studies (Regenberg et al., [12]; Castrillo et al., [13]; Brauer et al., [14]; Fazio et al., [present study]).

Click here for file

[http://www.biomedcentral.com/content/supplementary/14712164-9-341-S1.doc]

\section{Additional file 2}

Supplementary Methods. Details of the R code used for the analysis of CEL files.

Click here for file

[http://www.biomedcentral.com/content/supplementary/14712164-9-341-S2.pdf]

\section{Additional file 3}

Gene Lists, Gene Ontology and TF Interactions. This * .xls file contains 7 worksheets: (1) full annotation of the 114 (FDR 2\%) growth ratedependent genes up-regulated at increasing dilution rates; (2) full annotation of the 154 (FDR 2\%) growth rate-dependent genes down-regulated at increasing dilution rates; (3) full annotation of the nutrient limitation dependent genes (FDR 2\%); (4) full annotation of the oxygen availability dependent genes at (FDR 2\%); (5-6) Gene Ontology analysis (Process, Function, Component) of the up/down-regulated growth rate genes performed by using GO Term Finder and GO Slim Mapper available at the Saccharomyces Genome Database (SGD) website; (7) Detailed description of the interactions of the transcription factor network presented in figure 4 of the paper.

Click here for file

[http://www.biomedcentral.com/content/supplementary/14712164-9-341-S3.xls]

\section{Acknowledgements}

We thank Lene Christiansen and Koen de Graaf for technical support. This work was supported by the Danish Research Agency for Technology and Production. M.C.J. is grateful to the NSF International Research Fellowship Program for supporting his work. The research group of J.T.P. is part of the 
Kluyver Centre for Genomics of Industrial Fermentation, which is funded by the Netherlands Genomics Initiative.

\section{References}

I. DeRisi JL, lyer VR, Brown PO: Exploring the metabolic and genetic control of gene expression on a genomic scale. Science 1997, 278(5338):680-686.

2. Wodicka L, Dong H, Mittmann M, Ho MH, Lockhart DJ: Genomewide expression monitoring in Saccharomyces cerevisiae. Nat Biotechnol I997, I5(I3): I359-I367.

3. Boer VM, de Winde JH, Pronk JT, Piper MD: The genome-wide transcriptional responses of Saccharomyces cerevisiae grown on glucose in aerobic chemostat cultures limited for carbon, nitrogen, phosphorus, or sulfur. I Biol Chem 2003, 278(5):3265-3274.

4. Wu J, Zhang N, Hayes A, Panoutsopoulou K, Oliver SG: Global analysis of nutrient control of gene expression in Saccharomyces cerevisiae during growth and starvation. Proc Natl Acad Sci U S A 2004, I 0 I(9):3 I 48-3I 53.

5. Usaite R, Patil KR, Grotkjaer T, Nielsen J, Regenberg B: Global transcriptional and physiological responses of Saccharomyces cerevisiae to ammonium, L-alanine, or L-glutamine limitation. Appl Environ Microbiol 2006, 72(9):6194-6203.

6. ter Linde JJ, Liang H, Davis RW, Steensma HY, van Dijken JP, Pronk JT: Genome-wide transcriptional analysis of aerobic and anaerobic chemostat cultures of Saccharomyces cerevisiae. J Bacteriol 1999, I8I(24):7409-74I3.

7. Piper MD, Daran-Lapujade P, Bro C, Regenberg B, Knudsen S, Nielsen J, Pronk JT: Reproducibility of oligonucleotide microarray transcriptome analyses. An interlaboratory comparison using chemostat cultures of Saccharomyces cerevisiae. J Biol Chem 2002, 277(40):3700I-37008.

8. Tai SL, Boer VM, Daran-Lapujade P, Walsh MC, de Winde JH, Daran JM, Pronk JT: Two-dimensional transcriptome analysis in chemostat cultures. Combinatorial effects of oxygen availability and macronutrient limitation in Saccharomyces cerevisiae. I Biol Chem 2005, 280(I):437-447.

9. Hayes A, Zhang N, Wu J, Butler PR, Hauser NC, Hoheisel JD, Lim FL, Sharrocks AD, Oliver SG: Hybridization array technology coupled with chemostat culture: Tools to interrogate gene expression in Saccharomyces cerevisiae. Methods 2002, 26(3):28I-290.

10. Daran-Lapujade P, Jansen ML, Daran JM, van Gulik W, de Winde JH, Pronk JT: Role of transcriptional regulation in controlling fluxes in central carbon metabolism of Saccharomyces cerevisiae. A chemostat culture study. J Biol Chem 2004, 279(10):9125-9138.

II. Hoskisson PA, Hobbs G: Continuous culture--making a comeback? Microbiology 2005, I 5 I (Pt I 0):3 I53-3I59.

12. Regenberg B, Grotkjaer T, Winther O, Fausboll A, Akesson M, Bro $C$, Hansen LK, Brunak S, Nielsen J: Growth-rate regulated genes have profound impact on interpretation of transcriptome profiling in Saccharomyces cerevisiae. Genome Biol 2006, 7(I I):RI07.

13. Castrillo II, Zeef LA, Hoyle DC, Zhang N, Hayes A, Gardner DC, Cornell MJ, Petty J, Hakes L, Wardleworth L, Rash B, Brown M, Dunn WB, Broadhurst D, O'Donoghue K, Hester SS, Dunkley TP, Hart SR, Swainston N, Li P, Gaskell SJ, Paton NW, Lilley KS, Kell DB, Oliver SG: Growth control of the eukaryote cell: a systems biology study in yeast. J Biol 2007, 6(2):4.

14. Brauer MJ, Huttenhower C, Airoldi EM, Rosenstein R, Matese JC, Gresham D, Boer VM, Troyanskaya OG, Botstein D: Coordination of growth rate, cell cycle, stress response, and metabolic activity in yeast. Mol Biol Cell 2008, I 9(I):352-367.

15. Pir P, Kirdar B, Hayes A, Onsan ZY, Ulgen KO, Oliver SG: Integrative investigation of metabolic and transcriptomic data. $B M C$ Bioinformatics 2006, 7:203.

16. Xie Y, Varshavsky A: RPN4 is a ligand, substrate, and transcriptional regulator of the $26 \mathrm{~S}$ proteasome: a negative feedback circuit. Proc Natl Acad Sci U S A 2001, 98(6):3056-306I.

17. Hanna J, Finley D: A proteasome for all occasions. FEBS Lett 2007, 58 I(I 5):2854-286I.

18. Patil KR, Nielsen J: Uncovering transcriptional regulation of metabolism by using metabolic network topology. Proc Natl Acad Sci U S A 2005, 102(8):2685-2689.
19. Nielsen J, Jewett MC: Impact of systems biology on metabolic engineering of Saccharomyces cerevisiae. FEMS Yeast Res 2008, 8(I): $|22-| 3 \mid$.

20. Beyer A, Workman C, Hollunder J, Radke D, Moller U, Wilhelm T, Ideker T: Integrated assessment and prediction of transcription factor binding. PLoS Comput Biol 2006, 2(6):e70.

2I. Harbison CT, Gordon DB, Lee TI, Rinaldi NJ, Macisaac KD, Danford TW, Hannett NM, Tagne JB, Reynolds DB, Yoo J, Jennings EG, Zeitlinger J, Pokholok DK, Kellis M, Rolfe PA, Takusagawa KT, Lander ES, Gifford DK, Fraenkel E, Young RA: Transcriptional regulatory code of a eukaryotic genome. Nature 2004, 43 I (7004):99-I04.

22. Warner JR: The economics of ribosome biosynthesis in yeast. Trends Biochem Sci 1999, 24(I I):437-440.

23. Morse RH: RAP, RAP, open up! New wrinkles for RAPI in yeast. Trends Genet 2000, I 6(2):5I-53

24. Lieb JD, Liu X, Botstein D, Brown PO: Promoter-specific binding of Rap I revealed by genome-wide maps of protein-DNA association. Nat Genet 200I, 28(4):327-334.

25. Kraakman LS, Griffioen G, Zerp S, Groeneveld P, Thevelein JM, Mager WH, Planta RJ: Growth-related expression of ribosomal protein genes in Saccharomyces cerevisiae. Mol Gen Genet 1993, 239(I-2): 196-204.

26. Lee TI, Rinaldi NJ, Robert F, Odom DT, Bar-Joseph Z, Gerber GK, Hannett NM, Harbison CT, Thompson CM, Simon I, Zeitlinger J, Jennings EG, Murray HL, Gordon DB, Ren B, Wyrick JJ, Tagne JB, Volkert TL, Fraenkel E, Gifford DK, Young RA: Transcriptional regulatory networks in Saccharomyces cerevisiae. Science 2002, 298(5594):799-804.

27. Schawalder SB, Kabani M, Howald I, Choudhury U, Werner M, Shore D: Growth-regulated recruitment of the essential yeast ribosomal protein gene activator IfhI. Nature 2004, 432(7020): |058-106|.

28. Wade JT, Hall DB, Struhl K: The transcription factor Ifh I is a key regulator of yeast ribosomal protein genes. Nature 2004, 432(7020): $1054-1058$.

29. Rudra D, Zhao Y, Warner JR: Central role of Ifh I p-FhIl p interaction in the synthesis of yeast ribosomal proteins. Embo 2005, 24(3):533-542.

30. Simon I, Barnett J, Hannett N, Harbison CT, Rinaldi NJ, Volkert TL, Wyrick J, Zeitlinger J, Gifford DK, Jaakkola TS, Young RA: Serial regulation of transcriptional regulators in the yeast cell cycle. Cell 200I, I 06(6):697-708.

31. Horak CE, Luscombe NM, Qian J, Bertone P, Piccirrillo S, Gerstein M, Snyder M: Complex transcriptional circuitry at the GI/S transition in Saccharomyces cerevisiae. Genes Dev 2002 , 16(23):3017-3033.

32. Laabs TL, Markwardt DD, Slattery MG, Newcomb LL, Stillman DJ, Heideman W: ACE2 is required for daughter cell-specific $\mathbf{G}$ I delay in Saccharomyces cerevisiae. Proc Natl Acad Sci U S A 2003, I 00( I 8): 10275-10280.

33. Ho Y, Gruhler A, Heilbut A, Bader GD, Moore L, Adams SL, Millar A Taylor P, Bennett K, Boutilier K, Yang L, Wolting C, Donaldson I, Schandorff S, Shewnarane J, Vo M, Taggart J, Goudreault M, Muskat B, Alfarano C, Dewar D, Lin Z, Michalickova K, Willems AR, Sassi H, Nielsen PA, Rasmussen KJ, Andersen JR, Johansen LE, Hansen LH, Jespersen $H$, Podtelejnikov A, Nielsen E, Crawford J, Poulsen V Sorensen BD, Matthiesen J, Hendrickson RC, Gleeson F, Pawson T, Moran MF, Durocher D, Mann M, Hogue CW, Figeys D, Tyers M: Systematic identification of protein complexes in Saccharomyces cerevisiae by mass spectrometry. Nature 2002, 4|5(6868): | $80-\mid 83$.

34. Kasten MM, Stillman DJ: Identification of the Saccharomyces cerevisiae genes STB I-STB5 encoding Sin3p binding proteins. Mol Gen Genet 1997, 256(4):376-386.

35. Jorgensen P, Rupes I, Sharom JR, Schneper L, Broach JR, Tyers M: A dynamic transcriptional network communicates growth potential to ribosome synthesis and critical cell size. Genes Dev 2004, I 8(20):249|-2505

36. Marion RM, Regev A, Segal E, Barash Y, Koller D, Friedman N, O'Shea EK: Sfp I is a stress- and nutrient-sensitive regulator of ribosomal protein gene expression. Proc Natl Acad Sci U S A 2004, I 0 | (40): | 43 | 5-|4322.

37. Jorgensen P, Nishikawa JL, Breitkreutz BJ, Tyers M: Systematic identification of pathways that couple cell growth and division in yeast. Science 2002, 297(5580):395-400. 
38. Cipollina C, Alberghina L, Porro D, Vai M: SFPI is involved in cell size modulation in respiro-fermentative growth conditions. Yeast 2005, 22(5):385-399.

39. Jorgensen $P$, Tyers $M$ : How cells coordinate growth and division. Curr Biol 2004, I4(23):R I 0 I4-27.

40. Temple MD, Perrone GG, Dawes IW: Complex cellular responses to reactive oxygen species. Trends Cell Biol 2005, I 5(6):319-326.

4I. Chua G, Morris QD, Sopko R, Robinson MD, Ryan O, Chan ET, Frey BJ, Andrews BJ, Boone C, Hughes TR: Identifying transcription factor functions and targets by phenotypic activation. Proc Natl Acad Sci U S A 2006, I 03(32): I 2045-I 2050.

42. Mendizabal I, Rios G, Mulet JM, Serrano R, de Larrinoa IF: Yeast putative transcription factors involved in salt tolerance. FEBS Lett 1998, 425(2):323-328.

43. Steinfeld I, Shamir R, Kupiec M: A genome-wide analysis in Saccharomyces cerevisiae demonstrates the influence of chromatin modifiers on transcription. Nat Genet 2007, 39(3):303-309.

44. DeRisi J, van den Hazel B, Marc P, Balzi E, Brown P, Jacq C, Goffeau $A$ : Genome microarray analysis of transcriptional activation in multidrug resistance yeast mutants. FEBS Lett 2000, 470(2): I56-160.

45. Workman CT, Mak HC, McCuine S, Tagne JB, Agarwal M, Ozier O, Begley TJ, Samson LD, Ideker T: A systems approach to mapping DNA damage response pathways. Science 2006, 3 | 2(5776): 1054-1059.

46. Grotkjaer T, Winther O, Regenberg B, Nielsen J, Hansen LK: Robust multi-scale clustering of large DNA microarray datasets with the consensus algorithm. Bioinformatics 2006, 22(I):58-67.

47. van Dijken JP, Bauer J, Brambilla L, Duboc P, Francois JM, Gancedo C, Giuseppin ML, Heijnen J], Hoare M, Lange HC, Madden EA, Niederberger P, Nielsen J, Parrou JL, Petit T, Porro D, Reuss M, van Riel N, Rizzi M, Steensma HY, Verrips CT, Vindelov J, Pronk JT: An interlaboratory comparison of physiological and genetic properties of four Saccharomyces cerevisiae strains. Enzyme Microb Technol 2000, 26(9-10):706-714.

48. Affymetrix: Affymetrix GeneChip Expression Analysis Technical Manual. Affymetrix, Santa Clara, CA. 2000.

49. Gautier L, Cope L, Bolstad BM, Irizarry RA: affy--analysis of Affymetrix GeneChip data at the probe level. Bioinformatics 2004, 20(3):307-3I5.

50. Wu Z, Irizarry RA, Gentleman R, Martínez-Murillo F, Spencer F: A model based background adjustment for oligonucleotide expression arrays. Johns Hopkins University, Dept of Biostatistics Working Papers Working Paper I 2004 [http://www.bepress.com/cgi/ viewcontent.cgi? article $=100 \mid$ \&context $=$ jhubiostat $]$.

51. Workman C, Jensen LJ, Jarmer H, Berka R, Gautier L, Nielser HB, Saxild HH, Nielsen C, Brunak S, Knudsen S: A new non-linear normalization method for reducing variability in DNA microarray experiments. Genome Biol 2002, 3(9):research0048.

52. Irizarry RA, Hobbs B, Collin F, Beazer-Barclay YD, Antonellis KJ, Scherf U, Speed TP: Exploration, normalization, and summaries of high density oligonucleotide array probe level data. Biostatistics 2003, 4(2):249-264.

53. Churchill GA: Using ANOVA to analyze microarray data. Biotechniques 2004, 37(2): I73-5, I77.

54. Cui X, Hwang JT, Qiu J, Blades NJ, Churchill GA: Improved statistical tests for differential gene expression by shrinking variance components estimates. Biostatistics 2005, 6(I):59-75.

55. Storey JD, Tibshirani R: Statistical significance for genomewide studies. Proc Natl Acad Sci U S A 2003, I 00( I 6):9440-9445.

56. Benjamini $Y$, Hochberg Y: Controlling the False Discovery Rate: a practical and powerful approach to multiple testing. J R Statist Soc B 1995, 57(I289-300 [http://www.biostat.jhsph.edu/ -yonchen/Controlling\%20the\%20false\%20discovery\%20rate.pdf].

57. Dwight SS, Harris MA, Dolinski K, Ball CA, Binkley G, Christie KR, Fisk DG, Issel-Tarver L, Schroeder M, Sherlock G, Sethuraman A, Weng S, Botstein D, Cherry JM: Saccharomyces Genome Database (SGD) provides secondary gene annotation using the Gene Ontology (GO). Nucleic Acids Res 2002, 30(I):69-72.

58. Stark C, Breitkreutz BJ, Reguly T, Boucher L, Breitkreutz A, Tyers M: BioGRID: a general repository for interaction datasets. Nucleic Acids Res 2006, 34(Database issue):D535-9.

59. Shannon P, Markiel A, Ozier O, Baliga NS, Wang JT, Ramage D, Amin $\mathrm{N}$, Schwikowski B, Ideker T: Cytoscape: a software environment for integrated models of biomolecular interaction networks. Genome Res 2003, I 3( I I):2498-2504.
Publish with Biomed Central and every scientist can read your work free of charge

"BioMed Central will be the most significant development for disseminating the results of biomedical research in our lifetime. "

Sir Paul Nurse, Cancer Research UK

Your research papers will be:

- available free of charge to the entire biomedical community

- peer reviewed and published immediately upon acceptance

- cited in PubMed and archived on PubMed Central

- yours - you keep the copyright 